\title{
Effect of biocomposite edible coatings based on pea starch and guar gum on nutritional quality of 'Valencia' orange during storage ${ }^{\dagger}$
}

\author{
Bahareh Saberi ${ }^{*}$ \\ John B. Golding 1,2 \\ Suwimol Chockchaisawasdee ${ }^{1,3}$ \\ Christopher J. Scarlett ${ }^{1}$ \\ Costas E. Stathopoulos ${ }^{3}$
}

${ }^{1}$ School of Environmental and Life Sciences, University of Newcastle, Ourimbah, NSW 2258, Australia

${ }^{2}$ NSW Department of Primary Industries, Ourimbah, NSW 2258, Australia

${ }^{3}$ Division of Food and Drink, School of Science, Engineering and Technology, University of Abertay, Dundee DD1 1HG, UK

*Correspondence to: Bahareh Saberi

School of Environmental and Life Sciences, Faculty of Science and Information Technology, University of Newcastle, Brush Road, Ourimbah, NSW 2258, Australia.

Tel: +61 449968763; Fax: +61 24348 4145; E-mail: bahareh.saberi@uon.edu.au

${ }^{\dagger}$ This article has been accepted for publication and undergone full peer review but has not been through the copyediting, typesetting, pagination and proofreading process, which may lead to differences between this version and the Version of Record. Please cite this article as doi: [10.1002/star.201700299].

This article is protected by copyright. All rights reserved.

Received: October 28, 2017 / Revised: December 21, 2017 / Accepted: February 7, 2018

This article may be used for non-commercial purposes in accordance with the Wiley Self-Archiving Policy 


\section{Abstract}

Application of environmentally friendly components is an approach for substitution of synthetic substances in commercial waxes applied to citrus. In this study, the effect of biocomposite edible coatings based on pea starch and guar gum (PSGG) on total vitamin C,

phenolic, flavonoid, anthocyanins, and carotenoid content, and antioxidant capacity of 'Valencia' orange stored at $5{ }^{\circ} \mathrm{C}$ and $20^{\circ} \mathrm{C}$ for four weeks were evaluated. The fruits were coated by a single layer PSGG coating, blended composite PSGG coating containing shellac (Sh) and oleic acid as hydrophobic compounds (PSGG-Sh), and a layer-by-layer (LBL) coating (PSGG as an internal layer and Sh as an external layer). The results showed no significant differences in changes of bioactive compounds between coating treatments after first week storage at both temperatures. The PSGG coatings incorporated with hydrophobic compounds (PSGG-Sh) better preserved the nutritional value and the antioxidant potential of oranges during storage compared with other treatments. The single layer PSGG coating was almost similar to bilayer coating in preserving nutritional value of fruit during storage and less effective than the blended composite PSGG-Sh coating.

Keywords: Starch edible coating; Bioactive compounds; Nutritional quality; Citrus

\section{Abbreviations:}

PSGG: Pea starch-guar gum, Sh: Shellac, PSGG-Sh: Pea starch-guar gum with shellac, LBL: Layer-by-layer, CW: Commercial wax, OA: Oleic acid, RH: Relative humidity, TA: Titratable acidity, TSS: Total soluble solids, AAE: Ascorbic acid equivalents, TPC: Total phenolic content, GAE: Gallic acid equivalents, TFC: Total flavonoid content, RE: Rutin equivalents, TAC: Total anthocyanins, CGE: Cyanidin-3-glucoside equivalents, DPPH: 1,1diphenyl-2-picrylhydrazyl, TE: Trolox equivalents, FRAP: Ferric reducing antioxidant power, TPTZ: 2,4,6-tripyridyl-s-triazine. 


\section{Introduction}

Citrus fruits are widely consumed all over the world because of their flavor, valuable nutrients, and extensive accessibility [1]. The health beneficial impacts of citrus fruits are mostly associated with the existence of bioactive compounds such as the ascorbic acid, polyphenolic compounds, and flavonoids [2, 3]. Therefore, it is essential to develop reliable and simple technologies to maintain both nutritional and functional quality of citrus fruits during storage until they reach the consumer.

Application of edible coatings as new technique have become important in horticultural science due to their efficiency in preservation of the quality and extension the shelf life of fresh products and in reduction the senescence rate by reducing weight loss, moisture and gas movement, and oxidative reaction and respiration rates [4]. Edible coatings are prepared from various food-grade and safe compounds comprising polysaccharides, proteins and lipids [5], which offer benefits and drawbacks once applied as coating ingredients. In general, owing to hydrophobic nature of lipids, they act as moisture barrier and decrease weight loss, shrinkage, and shriveling of coated fruit. Though, their non-polymeric nature restricts their capability to produce homogenous films [6]. Conversely, polysaccharides and proteins form cohesive films with poor moisture barriers and intermediate oxygen barriers due to their hydrophilic nature [7]. Therefore 'edible composite coatings' containing a mixture of ingredients have been developed for coating fresh fruit and vegetables [8].

In our previous studies, it has been demonstrated that pea starch in combination with guar gum produced biocomposite edible films with desirable physical, optical and mechanical characteristics [9-11]. It was shown that pea starch and guar gum can be potential alternatives for production of renewable source based biodegradable edible coatings owing to their long polymeric chain, high molecular weight and wide availability. However because of the 
hydrophilic nature of pea starch and guar gum, a hydrophobic substance is necessary to be added to the pea starch and guar gum edible coatings (PSGG) to decrease the water sensitivity of the coating [12].

Citrus is Australia's largest fresh fruit export (www.citrusaustralia.com.au). Because of the distance between Australia and other countries, the transportation of fresh products causes problems. Therefore, the shelf-life of fruit may decrease resulting in overall poor fruit consumer acceptability. In Australia, the harvested citrus fruits go through a coating (waxing) procedure for commercial purposes, which is an effective approach to extent shelf-life of fruit. Though, waxing alters the internal atmosphere inducing anaerobic off-flavor development with the simultaneous confining gas exchange. Application of environmentally friendly components is an approach for substitution of synthetic substances applied in commercial waxes. In this study, we investigated the potential application of edible coatings made from biodegradable and edible ingredients (pea starch and guar gum) for maintaining the nutritional quality and extending the shelf life of fresh 'Valencia' oranges stored at various storage conditions.

Therefore, the influence of various polysaccharide-based edible coatings including pea starch-guar gum (PSGG), pea starch-guar gum-shellac (PSGG-Sh), and PSGG/Sh bilayer composite coating, formed by first applying PSGG and then shellac (Sh) were compared with fruits coated with commercial wax and uncoated fruits (control) on maintaining the nutritional quality and antioxidant properties of fresh 'Valencia' oranges during four weeks of storage at $20^{\circ} \mathrm{C}$ and $5{ }^{\circ} \mathrm{C}$. The effect of edible coatings on the physical properties of treated 'Valencia' oranges was investigated in another study.

\section{Materials and methods}

\subsection{Materials}


Canadian non-GMO yellow pea starch with $13.2 \%$ moisture, $0.2 \%$ protein, $0.5 \%$ fat, $0.3 \%$ ash, and $36.25 \%$ amylose was used in all experiments (supplied by Yantai Shuangta Food Co., Jinling Town, China). Guar gum (E-412) was purchased from The Melbourne Food Ingredient Depot, Brunswick East, Melbourne, Australia. Food grade shellac and 'Citrus Gleam' (shellac based commercial wax) were purchased from Castle Chemicals, NSW, Australia. Oleic acid (OA) and Tween-20 were obtained from Sigma Aldrich, Australia. Glycerol was from Ajax Finechem Pty. Ltd, Australia and used as a plasticizer. All other chemicals (sodium hydroxide, sodium phosphate, ammonium molybdate, sulfuric acid, ascorbic acid, sodium carbonate, gallic acid, rutin, sodium nitrite, aluminium chloride, potassium chloride, sodium acetate, cyanidin-3-glucoside, n-hexane, acetone, $\beta$-carotene, DPPH (1,1-diphenyl-2-picrylhydrazyl), trolox, and TPTZ (2,4,6-tripyridyl-s-triazine)) were purchased from Merck Millipore, Pty., VIC, Melbourne, Australia.

\subsection{Sample preparation}

'Valencia’ oranges (Citrus sinensis L. Osbeck) were obtained from a local commercial citrus grower (Griffith, NSW, Australia) at commercial maturity and transported to the NSW Department of Primary Industries (Ourimbah, NSW, Australia). Oranges were selected based on homogeneity in shape, color, size, firmness and free of mechanical wounds or fungal decay. Selected oranges were sanitized by dipping in a solution of $1150 \mathrm{ppm}$ fludioxonil (as fungicide) (Scholar ${ }^{\circledR}$, Syngenta Australia) for one min, then drained and air-dried at $20^{\circ} \mathrm{C}$ before coating application.

\subsection{Coating formulations}

\subsubsection{PSGG coatings}


Pea starch (2.5 g), guar gum (0.3 g) and $25 \%$ w/w glycerol as plasticizer based on the dry film matter were dissolved in $100 \mathrm{~mL}$ degassed deionized water. The solution was heated at $90{ }^{\circ} \mathrm{C}$ for 20 min upon constant stirring. The suspension was then cooled until room temperature with mild magnetic stirring [10]. The film solution was prepared one day before use.

\subsubsection{PSGG-Sh coatings}

The PSGG-Sh composite mixture was prepared by adding oleic acid (1 \% of dry weight of pea starch and guar gum) as emulsifier and Tween-20 (0.3 mL) as surfactant to the PSGG solution made as described above. Shellac at $40 \%$ (dry weight of pea starch and guar gum) was added to the PSGG-oleic acid-Tween 20-glycerol mixture. These levels of film ingredients were optimized using Box-Behnken response surface design [12]. The emulsion was gelatinized at $90{ }^{\circ} \mathrm{C}$ for $20 \mathrm{~min}$ on a hot plate with continuous stirring. Once the lipids had melted, samples were homogenized for 4 min at 22,000 rpm using a T25 Ultra-Turrax (Ika, Staufen, Germany). After homogenization, the film solution was cooled to room temperature with slow magnetic stirring. The emulsion was prepared one day before use and was shown to be stable with no phase separation.

\subsection{Experimental design}

Five series of treatments were applied on oranges: (i) PSGG; (ii) PSGG-Sh; (iii) bilayer formulation of PSGG as an inner layer with Sh as an external layer (PSGG/Sh); (iv) CW (commercial wax, shellac based ‘Citrus Gleam’, Castle Chemicals Australia) and (v) distilled water acting as a control. Each treatment for each storage condition included 128 oranges with 8 oranges per plastic netted bag. There were four replicates per treatment with each bag considered a single replicate. Data were recorded before treatment (day 0) and after one week and four weeks storage at $20^{\circ} \mathrm{C}$ at relative humidity (RH) of 90-95\%. Another set of 
samples was also stored for 1 week and 4 weeks at $5{ }^{\circ} \mathrm{C}$ and $90-95 \% \mathrm{RH}$, followed by one additional week at $20^{\circ} \mathrm{C}$ [13].

\subsection{Fruit treatment and storage}

Each coating solution was sprayed uniformly on the whole surface of the fruits by using a paint sprayer (High Volume Low Pressure system, 500 W Paint Sprayer, 909, Mooroolbark, VIC, Australia). The bilayer coatings were applied as follows: first the PSGG coating was applied and fruits were dried at room temperature for $2-3$ min and then the Sh coating was applied. Then, all coated oranges were air-dried for $1 \mathrm{~h}$ at $20^{\circ} \mathrm{C}$, labelled, weighed, and then randomly packed into experimental units. Fruits were destructively measured after one week and four weeks storage at $20^{\circ} \mathrm{C}$ and $5^{\circ} \mathrm{C}$ at $90-95 \%$ RH. Four oranges from each replicate were assessed upon removal at $5{ }^{\circ} \mathrm{C}$ (when the fruit had reached room temperature) and the remaining four fruit were stored for another week at $20{ }^{\circ} \mathrm{C}$ to simulate retail handling and marketing conditions.

\subsection{Standard chemical analysis}

Two samples of 8 oranges per replicate were cut in half and hand-squeezed with a domestic citrus juice extractor under the same conditions of extraction and filtered with a domestic fine mesh strainer to remove pulp and seeds. The titratable acidity (TA) was assessed by titration $3 \mathrm{~mL}$ of orange juice to $\mathrm{pH} 8.2$ with sodium hydroxide $(0.1 \mathrm{~N})$ using an automatic titrator (Mettler Toledo T50, Switzerland) and expressed as \% citric acid. The $\mathrm{pH}$ of the juice sample was recorded at the same time. Total soluble solids (TSS) were measured as ${ }^{\circ}$ Brix using hand refractometer (ATAGO Inc., Bellevue, WA, USA) using the same juice sample [14].

\subsection{Total vitamin C}


Total vitamin C in orange juice was measured according to procedure described by Vuong, Hirun, Chuen, Goldsmith, Bowyer, Chalmers, Phillips and Scarlett [15]. A solution was prepared by mixing $5.32 \mathrm{~g}$ of sodium phosphate and $2.47 \mathrm{~g}$ of ammonium molybdate with $500 \mathrm{~mL}$ of $0.6 \mathrm{M}$ sulfuric acid. $0.3 \mathrm{~mL}$ of diluted sample was added to $3 \mathrm{~mL}$ of the prepared solution and incubated in a water bath at $95{ }^{\circ} \mathrm{C}$ for $90 \mathrm{~min}$. Absorbance of solution was then read by a UV Vis spectrophotometer (Varian Australia Pty. Ltd., Melbourne, VIC Australia) at $695 \mathrm{~nm}$ and compared against an ascorbic acid standard (range 6.25-100 $\mu \mathrm{g} / \mathrm{mL}$ ). The results were reported as mg ascorbic acid equivalents (AAE) per $100 \mathrm{~mL}$ of sample (mg AAE/100 mL).

\subsection{Total phenolic content (TPC)}

Orange juice $(1 \mathrm{~mL})$ was extracted with $9 \mathrm{~mL}$ of $80 \%$ methanol for $30 \mathrm{~min}$ at room temperature. After centrifugation at $5000 \mathrm{rpm}$ for $10 \mathrm{~min}$, the supernatant was taken out for measurement of total phenolics by Folin-Ciocalteu method as developed by Xu, Liu, Chen, Ye, Ma and Shi [16] with some modifications. Extract obtained (1 mL) of was added to a 25 $\mathrm{mL}$ volumetric flask filled with $9 \mathrm{~mL}$ distilled water and $4 \mathrm{~mL}$ of $7.5 \%$ (w/v) $\mathrm{Na}_{2} \mathrm{CO}_{3}$ was mixed with $1 \mathrm{~mL}$ of diluted sample and allowed to stand for 60 min before measurement at dark room. The absorbance was measured at $760 \mathrm{~nm}$ using a UV Vis spectrophotometer. Total phenolic content was expressed as mg gallic acid equivalents (GAE) per $100 \mathrm{~mL}$ of orange juice (mg GAE/100 mL).

\subsection{Total flavonoid content (TFC)}

Total flavonoid content (TFC) was measured according to the method used by Zhishen, Mengcheng and Jianming [17]. The results were presented as mg of rutin equivalents (RE) per $100 \mathrm{~mL}$ of sample (mg RE/100 mL). In short, $0.5 \mathrm{~mL}$ of orange juice was mixed with 2 $\mathrm{mL}$ of $\mathrm{H}_{2} \mathrm{O}$ and $0.15 \mathrm{~mL}$ of $5 \%(\mathrm{w} / \mathrm{v}) \mathrm{NaNO}_{2}$ and stand at room temperature for $6 \mathrm{~min}$. Then 
$0.15 \mathrm{~mL}$ of $10 \%(\mathrm{w} / \mathrm{v}) \mathrm{AlCl}_{3}$ was added to the solution and kept for another $6 \mathrm{~min}$. Finally, 2 $\mathrm{mL}$ of $4 \%(\mathrm{w} / \mathrm{v}) \mathrm{NaOH}$ and $0.7 \mathrm{~mL}$ of $\mathrm{H}_{2} \mathrm{O}$ were added and kept at room temperature for 15 min before the absorbance was measured at $510 \mathrm{~nm}$.

\subsection{Determination of total anthocyanins (TAC)}

The total anthocyanins (TAC) was calculated by pH-differential procedure presented by Lee, Durst and Wrolstad [18] with some changes, using two buffer systems: potassium chloride buffer (0.025 M, pH 1.0) and sodium acetate buffer (0.4 M, pH 4.5). Briefly, $9 \mathrm{~mL}$ of each buffer solution was mixed with $1 \mathrm{~mL}$ of juice sample and the absorbance was read at 520 and $700 \mathrm{~nm}$, respectively. The following equation was used to measure the total anthocyanins content and the results were expressed as mg of cyanidin-3-glucoside equivalents (CGE) per $100 \mathrm{~mL}$ of orange juice (mg CGE/100 mL):

Total anthocyanins $(\mathrm{mg} / \mathrm{L})=\mathrm{Abs} \times \mathrm{M}_{\mathrm{w}} \times \mathrm{DF} \times 1000 /(\varepsilon \times 1)$

where Abs $=\left(\mathrm{Abs}_{520}-\mathrm{Abs}_{700}\right)_{\mathrm{pH}}=1.0-\left(\mathrm{Abs}_{520}-\mathrm{Abs}_{700}\right)_{\mathrm{pH}}=4.5, \mathrm{MW}=$ molecular weight, $\mathrm{DF}=$ dilution factor, 1 = path length $(1 \mathrm{~cm})$, pigment contents were calculated as malvidin-3-Oglucoside using an extinction coefficient $\varepsilon$ of $28,000 \mathrm{~L} \mathrm{~mol}^{-1} \mathrm{~cm}^{-1}$ and a molecular weight of $493.2 \mathrm{~g} \mathrm{~mol}^{-1}, 1000=$ conversion from $\mathrm{g}$ to $\mathrm{mg}$.

\subsection{Total carotenoid content}

Juice samples (25 mL) were mixed with $80 \mathrm{~mL}$ of extracting solvent (n-hexane/acetone, 1:1). After shaking in a separation funnel during $30 \mathrm{~min}$, the upper phase was recovered. $15 \mathrm{~mL}$ of n-hexane/acetone $(1: 1, v / v)$ were added and extraction was repeatedly carried out until the aqueous phase was colorless. The mixture of the extractions was saponified using $5 \mathrm{~mL}$ of methanolic $10 \%(\mathrm{w} / \mathrm{v})$ potassium hydroxide solution in a dark room for $2 \mathrm{~h}$. The saponified mixture was then transferred to a separatory funnel and mixed with $20 \mathrm{~mL}$ of deionized water 
to separate the upper hexane layer containing the carotenoids. The hexane layer was collected, washed twice with $10 \mathrm{~mL}$ of deionized water, dehydrated with anhydrous sodium sulphate and filtered through a $0.45 \mu \mathrm{m}$ membrane. The absorbance of hexanic extract was calculated at $450 \mathrm{~nm}$ and carotenoid content was measured from the $\beta$-carotene calibration curve [19]. The results were described as mg of $\beta$-carotene per $L$ of juice.

\subsection{Total antioxidant activity}

\subsubsection{DPPH free radical-scavenging assay}

DPPH (1,1-diphenyl-2-picrylhydrazyl) radical scavenging activity was analyzed according to Vuong, Hirun, Roach, Bowyer, Phillips and Scarlett [20]. Briefly, $150 \mu \mathrm{L}$ of the extracted sample was mixed with $2800 \mu \mathrm{L}$ of DPPH methanolic solution and left in the dark room for 1 h. Absorbance was measured at $517 \mathrm{~nm}$. Results were shown in mg trolox equivalents (TE) per $100 \mathrm{~mL}$ of sample (mg TE/100 mL).

\subsubsection{Ferric reducing antioxidant power (FRAP) assay}

The ferric reducing ability of orange juice was measured as per a modified method established by Thaipong, Boonprakob, Crosby, Cisneros-Zevallos and Byrne [21]. Diluted sample $(0.15 \mathrm{~mL})$ was mixed with $2.85 \mathrm{~mL}$ of FRAP reagent (mixture of $0.1 \mathrm{M}$ acetate buffer (pH 3.6), $10 \mathrm{mM}$ TPTZ (2,4,6-tripyridyl-s-triazine), and $20 \mathrm{mM}$ ferric chloride (10:1:1 $\mathrm{v}: \mathrm{v}: \mathrm{v})$ ) and maintained at room temperature under dark for 30 min before its absorbance was taken at $593 \mathrm{~nm}$. Results were shown in mg trolox equivalents (TE) per $100 \mathrm{~mL}$ of sample (mg TE/100 mL).

\subsection{Statistical analysis}

The experiment had four independent replicates where each replicate was prepared and coated in an independent manner. All analyses were performed in quadruplicate. The results 
were statistically assessed by analysis of variance (ANOVA) and Multiple Ranges Duncan’s test to determine whether differences among treatments and storage time were significant at $p$ $<0.05$., using the software SPSS (version 23, SPSS Inc., Chicago, IL, USA).

\section{Results and discussions}

\subsection{Standard chemical analysis}

The influence of coating treatments on TSS, TA, and $\mathrm{pH}$ parameters during storage is shown in Table 1. TA reduced during storage time for all treatments analyzed, except in fruit coated with blended composite PSGG-Sh coating (there was no significant difference), which demonstrated delay in senescence [22]. TA, pH and TSS content in orange fruit before treatment was around $1.24 \pm 0.18 \%, 3.60 \pm 0.11$, and $11.94 \pm 0.48{ }^{\circ} \mathrm{Brix}$, respectively. The single layer PSGG and bilayer PSGG/Sh coatings were found to be as effective as CW in the maintenance of TA throughout the storage time. Upon removal from storage at $5{ }^{\circ} \mathrm{C}$, TA in non-coated fruit was lower than the treated fruit, but with storing an additional week at $20^{\circ} \mathrm{C}$, there was no significant difference in TA of fruit regardless of the coating type. The lower TA level in uncoated oranges link to the organic acid decrease because of the increase in respiration rate throughout storage [23]. Organic acids including citric and malic acids are the main substrates of respiration; thus, reduction of acidity happens in respiring fruit [24]. The decrease in TA during storage has been previously observed on coated citric fruits [23, 2527]. The preservation of TA in coated fruit compared with the control sample indicated that the polysaccharide based coatings retarded ripening by creating a semi-permeable barrier around the fruit [28].

TSS content of uncoated and coated fruit did not change during storage at $5{ }^{\circ} \mathrm{C}$ (Table 1 ). However, a slight increase in TSS content of orange juice for all treatments as function of storage time was observed in all storage conditions. No significant differences in TSS content 
were found among uncoated and coated oranges at first week storage at $20^{\circ} \mathrm{C}$ and $5{ }^{\circ} \mathrm{C}$. TSS content of LBL coating was similar to that of CW in all storage assessments. TSS content of fruit coated with composite PSGG-Sh was significantly lower after four weeks storage period at $5{ }^{\circ} \mathrm{C}$ followed by one week at $20^{\circ} \mathrm{C}$, and at constant $20^{\circ} \mathrm{C}$. Changes of TSS in fruit are attributed to the basic metabolic reactions and level of maturity that increase the sugar and sweetness level in fruit through storage [29, 30]. As acid metabolism continues throughout storage, starch and acids convert into sugars for metabolic usage during fruit ripening and senescence [31]. The increase of TSS as function of storage time might be due to the moisture loss [32], ripening process [33], as well as softening mainly caused by the enzymatic degradation and turgor pressure reduction stimulated by moisture loss [34]. Furthermore, the releasing of soluble constituents owing to the solubilization of pectin, cellulose, and hemicellulose from cell walls under the influence of glucosidase and galactosidase present in fruit segments could have a clear impact on TSS [35]. These findings are in agreement with results of coating of oranges with chitosan containing essential oils [27] and with shellac, gelatin and Persian gum [25].

During the storage period, $\mathrm{pH}$ was significantly increased in all treatments, except in samples were treated with PSGG-Sh coating, as was expected in accordance with the results of the fruit acidity. The highest increase in $\mathrm{pH}$ was observed in control sample. Changes in $\mathrm{pH}$ might be owing to the impact of treatment on the biochemical condition particularly rate of respiration of the fruit [36].

\subsection{Changes in bioactive compounds}

Total vitamin $\mathrm{C}$ concentration of orange juice was decreased during the storage period in all treated and untreated samples (Fig. 1). The decrease of vitamin C by passage of time could be described by indirect degradation through polyphenol oxidase, cytochrome oxidase and 
peroxidase activity [37], which leads to more TSS [38]. After degradation, the similar structural formula of ascorbic acid to glucose results in increase of glucose and higher TSS [39]. Ascorbic acid is a water-soluble vitamin that can become irreversibly autoxidized into diketogolonic in presence of oxygen [40]. Treviño-Garza, García, del Socorro FloresGonzález and Arévalo-Niño [41] suggested that reduction in total vitamin C content was owing to high rate of respiration, oxidative deterioration, and accumulation of carbon dioxide in fruit. At the first week storage at $5{ }^{\circ} \mathrm{C}$, the content of total vitamin $\mathrm{C}$ in oranges was not influenced by applying different coatings (Fig. 1). After four weeks at refrigerator temperature, vitamin C content in samples coated with the blended composite PSGG-Sh and in uncoated fruit reduced $11 \%$ and $29 \%$, respectively. Since reduction in vitamin C content can be mainly affected by the presence of $\mathrm{O}_{2}$, the application of polysaccharide coatings may decrease $\mathrm{O}_{2}$ diffusion and accordingly decreases vitamin $\mathrm{C}$ loss of oranges. The bilayer coating was better than the CW coating in retarding vitamin C loss and less effective than the single layer PSGG coating. However, there was no significant difference in vitamin C loss of fruit coated by bilayer PSGG/Sh and CW at the end of storage at $20{ }^{\circ} \mathrm{C}$ and during 4 weeks of cold storage plus one week at $20^{\circ} \mathrm{C}$. Similar effects have been reported, where CMC edible coatings in mandarins [40] and in 'Newhall' navel oranges [26] delayed ascorbic acid loss during storage.

Changes during storage in the TPC in orange juice are shown in Fig. 2. Coating application did not have an important influence on the level of TPC during first week storage at $5{ }^{\circ} \mathrm{C}$ and $20{ }^{\circ} \mathrm{C}$. The maximum concentration of TPC was observed in PSGG-Sh coated fruit in all storage circumstances meaning that blended composite edible coating preserved higher amounts of antioxidants in fruit. The function of single layer PSGG and bilayer PSGG/Sh coatings on preserving the TPC in orange fruit was nearly similar to CW during storage time. This result can be described by the gas barrier of the coatings which reduced the potential 
oxidation of phenolic compounds in the presence of oxygen [6], and consequently strengthened the defense system and preserved the fruit quality throughout storage after harvest [42]. Day [43] declared that decrease of TPC in fruit during storage might be owing to the increased respiration rate, which brings about the loss of TPC because of the loss of certain phenolic compounds. It might be also as a result of senescence and degradation of cell structure throughout storage period [28], as well as the oxidative activity of polyphenol oxidase (PPO) enzyme converting phenol to quinones compound [44]. These results were in agreement with those found by Shamloo, Sharifani, Garmakhany and Seifi [38] for Valencia Orange and Contreras-Oliva, Rojas- Argudo and Pérez- Gago [6] in 'Oronules' mandarins.

Figure 3 shows the alterations in TFC of juice in treated and untreated oranges during storage. The results showed a slight but continuous decrease in TFC during whole storage time, showing high durability of this component [45]. The reduction trend is probably due to the activity of the manonyl transferase responsible for biosynthesis of flavonoids [46]. Del Caro, Piga, Vacca and Agabbio [47] and Rapisarda, Bianco, Pannuzzo and Timpanaro [48] reported that TFC reduced in different citrus families by increase storage time. Coating application did not have a considerable impact on the level of TFC at the first week of storage at $5{ }^{\circ} \mathrm{C}$, even though some significant differences were found among treatments at the end of storage, when compared with that of the control samples. The TFC level was higher at all polysaccharide based coated fruit compared with fruit coated with CW and non-coated fruit after four weeks storage at cold temperature. No significant difference was shown in TFC content of single PSGG, bilayer PSGG/Sh, and CW-coated fruit during additional one week storage at $20{ }^{\circ} \mathrm{C}$ after cold storage. Similar trend was observed at the end of storage at constant $20^{\circ} \mathrm{C}$.

The stability and color of anthocyanins are affected by oxygen, $\mathrm{pH}$, light, temperature, intermolecular and intramolecular interaction with metal ions and other compounds [19]. 
Results regarding the impact of coating treatments on total anthocyanins (TAC) of orange juice are presented in Fig. 4. A slight increase of juice anthocyanins in all samples was observed during storage, although uncoated control sample showed a more increase than the others. It has been suggested that anthocyanin content in orange increases during storage and its production is determined by activation of the enzymes involved in phenylpropanoid metabolism [49]. Moreover, reduction of citric acid in stored orange fruit may provide carbon skeletons for the synthesis of phenolics, particularly anthocyanins [48, 50]. No significant change was observed in TAC content for all treatments at first week of storage duration. Fruit treated with single, bilayer and CW coatings showed similar TAC content compared with uncoated fruit at the end of cold storage. Whereas, the TAC level in single layer PSGGcoated fruit was found to be lower than that in LBL and CW-coated fruit after 4 weeks storage at $5{ }^{\circ} \mathrm{C}$ followed by one week at $20^{\circ} \mathrm{C}$ and at the end of storage at constant $20^{\circ} \mathrm{C}$.

Orange juice is the most complex natural source of carotenoids [51]. The reason of instability, and subsequent reduction of carotenoids is because of the vulnerability to oxidation and geometric isomerization of its polyene chain during storage [52]. The total carotenoids of orange juice subjected to various coating treatments are demonstrated in Fig. 5. Compared with fresh fruit (11.73 mg $\beta$-carotene/L), total carotenoids of fruit remained stable at the beginning of storage, in particular during cold storage, but dropped thereafter. After one week of storage at $5{ }^{\circ} \mathrm{C}$ and one week at $5{ }^{\circ} \mathrm{C}$ plus one week at $20{ }^{\circ} \mathrm{C}$, no significant difference was observed on total carotenoids owing to coating application, which makes difficult to conclude about the influence of coating composition on this factor. Fruit coated with PSGG-Sh showed higher total carotenoids values than other samples. There was no significant difference in total carotenoid content of fruit coated by single and bilayer PSGG/Sh compared with CW coating during storage at $5{ }^{\circ} \mathrm{C}$. However, the single layer 
coating was better than the bilayer and CW coating in preserving total carotenoids during storage at constant $20^{\circ} \mathrm{C}$.

\subsection{Total antioxidant activity}

Changes in the maximum level of total antioxidant contents in orange juice during storage in terms of both DPPH and FRAP are shown in Table 2. Total antioxidant capacity DPPH and FRAP values in orange fruit before treatment was $131.34 \pm 2.46$ and $124.39 \pm 4.73$ (mg TE/100 mL), respectively. The use of polysaccharide-based edible coatings contributed to maintenance of antioxidant capacity of oranges over storage time. This behavior could be the result of the oxygen barrier characteristics of PSGG-based edible coatings to preserve fruit quality and to slow down enzyme activity and oxidative destruction of antioxidant compounds by postponing the biochemical and physiological changes happening throughout storage $[28,53]$. It has been reported that phenolic compounds, ascorbic acid and carotenoids contribute to antioxidant activity in citrus fruit $[6,54]$. The reduction in the antioxidant activity may be attributed to a lower content of phenolic compounds, vitamin $\mathrm{C}$ and carotenoids in fruit over storage as compared with fresh [45].

\section{Conclusion}

The influence of different polysaccharide edible coatings made from pea starch and guar gum on chemical and nutritional quality of 'Valencia' oranges during storage at 5 and $20{ }^{\circ} \mathrm{C}$ for four weeks was investigated. The incorporation of lipids to the PSGG coatings showed a beneficial impact on retention of bioactive compounds and nutritional quality of oranges during storage period. Furthermore, the bilayer coating contributed to the retention of bioactive compounds, however was not as effective as single layer PSGG coating. Degradation of bioactive compounds in all analyzed treatments was detected and became more obvious at ambient storage temperature and at extended storage. The results indicated 
that TFC, TAC, and total carotenoid were not most affected by coating treatment at early storage duration. The decrease in TPC, vitamin C and total carotenoid content upon storage was reflected by the decrease in DPPH and FRAP antioxidant activities of orange juice. Generally, the changes in chemical composition explained were in accordance with the low metabolic activity of this nonclimateric fruit after harvest. The slight variations among the compositional difference pattern for the various coated samples during the storage indicated that no unfavorable influence was stimulated by application of the coatings. Therefore, the use of PSGG edible coating could be considered as safe and applicable treatment to preserve antioxidant levels and, consequently, the health functionality of orange fruit during storage.

\section{Acknowledgement}

This study was funded by the University of Newcastle, NSW, Australia, the Australian Citrus Postharvest Science Program (CT15010) and Horticulture Innovation. The authors acknowledge personnel of the NSW Department of Primary Industries for their technical assistance on this project.

\section{Conflict of Interest}

The authors declare no conflict of interest.

\section{References}

[1] Liu, Y., Heying, E., Tanumihardjo, S. A., History, global distribution, and nutritional importance of citrus fruits. Compr. Rev. Food Sci. Food Saf. 2012, 11, 530-545.

[2] Sánchez-Moreno, C., Plaza, L., de Ancos, B., Cano, M. P., Quantitative bioactive compounds assessment and their relative contribution to the antioxidant capacity of commercial orange juices. J. Sci. Food Agric. 2003, 83, 430-439. 
[3] Louaileche, H., Khodja, Y. K., Bey, M. B., Phytochemical contents and in vitro antioxidant activity of algerian orange juices. Am. Inst. Sci. 2015, 1, 107-111.

[4] Robles-Sánchez, R. M., Rojas-Graü, M. A., Odriozola-Serrano, I., González-Aguilar, G., Martin-Belloso, O., Influence of alginate-based edible coating as carrier of antibrowning agents on bioactive compounds and antioxidant activity in fresh-cut Kent mangoes. $L W T$ Food Sci. Technol. 2013, 50, 240-246.

[5] Bai, J., Alleyne, V., Hagenmaier, R. D., Mattheis, J. P., Baldwin, E. A., Formulation of zein coatings for apples (Malus domestica Borkh). Postharvest Biol. Technol. 2003, 28, 259268.

[6] Contreras-Oliva, A., Rojas- Argudo, C., Pérez- Gago, M. B., Effect of solid content and composition of hydroxypropyl methylcellulose-lipid edible coatings on physico-chemical and nutritional quality of 'Oronules’ mandarins. J. Sci. Food Agric. 2012, 92, 794-802.

[7] Kester, J., Fennema, O., Edible films and coatings: a review. Food Technol. 1986.

[8] Falcao-Rodrigues, M. M., Moldao-Martins, M., Beirão-da-Costa, M. L., DSC as a tool to assess physiological evolution of apples preserved by edibles coatings. Food Chem. 2007, 102, 475-480.

[9] Saberi, B., Thakur, R., Bhuyan, D. J., Vuong, Q. V., Chockchaisawasdee, S., Golding, J. B., Scarlett, C. J., Stathopoulos, C. E., Development of edible blend films with good mechanical and barrier properties from pea starch and guar gum. Starch - Stärke 2016, 69, 115.

[10] Saberi, B., Thakur, R., Vuong, Q. V., Chockchaisawasdee, S., Golding, J. B., Scarlett, C. J., Stathopoulos, C. E., Optimization of physical and optical properties of biodegradable edible films based on pea starch and guar gum. Ind. Crops Prod. 2016, 86, 342-352. 
[11] Saberi, B., Vuong, Q. V., Chockchaisawasdee, S., Golding, J. B., Scarlett, C. J., Stathopoulos, C. E., Mechanical and physical properties of pea starch edible films in the presence of glycerol. J. Food Process. Preserv. 2016, 40, 1339-1351.

[12] Saberi, B., Chockchaisawasdee, S., Golding, J. B., Scarlett, C. J., Stathopoulos, C. E., Development of biocomposite films incorporated with different amounts of shellac, emulsifier, and surfactant. Food Hydrocoll. 2017, 72, 174-184.

[13] Saberi, B., Golding, J. B., Marques, J. R., Pristijono, P., Chockchaisawasdee, S., Scarlett, C. J., Stathopoulos, C. E., Application of biocomposite edible coatings based on pea starch and guar gum on quality, storability and shelf life of 'Valencia' oranges. Postharvest Biol. Technol. 2018, 137, 9-20.

[14] Pristijono, P., Papoutsis, K., Scarlett, C. J., Bowyer, M. C., Vuong, Q. V., Stathopoulos, C. E., Golding, J. B., Postharvest UV-C treatment combined with 1-methylcyclopropene (1MCP), followed by storage in continuous low-level ethylene atmosphere, improves the quality of tomatoes. J. Hortic. Sci. Biotechnol. 2017, 1-9.

[15] Vuong, Q. V., Hirun, S., Chuen, T. L., Goldsmith, C. D., Bowyer, M. C., Chalmers, A. C., Phillips, P. A., Scarlett, C. J., Physicochemical composition, antioxidant and antiproliferative capacity of a lilly pilly (Syzygium paniculatum) extract. J. Herb. Med. 2014, 4, 134-140.

[16] Xu, G., Liu, D., Chen, J., Ye, X., Ma, Y., Shi, J., Juice components and antioxidant capacity of citrus varieties cultivated in China. Food Chem. 2008, 106, 545-551.

[17] Zhishen, J., Mengcheng, T., Jianming, W., The determination of flavonoid contents in mulberry and their scavenging effects on superoxide radicals. Food Chem. 1999, 64, 555559. 
[18] Lee, J., Durst, R. W., Wrolstad, R. E., Determination of total monomeric anthocyanin pigment content of fruit juices, beverages, natural colorants, and wines by the $\mathrm{pH}$ differential method: collaborative study. J. AOAC Int. 2005, 88, 1269-1278.

[19] Abid, M., Jabbar, S., Wu, T., Hashim, M. M., Hu, B., Lei, S., Zeng, X., Sonication enhances polyphenolic compounds, sugars, carotenoids and mineral elements of apple juice. Ultrason. Sonochem. 2014, 21, 93-97.

[20] Vuong, Q. V., Hirun, S., Roach, P. D., Bowyer, M. C., Phillips, P. A., Scarlett, C. J., Effect of extraction conditions on total phenolic compounds and antioxidant activities of Carica papaya leaf aqueous extracts. J. Herb. Med. 2013, 3, 104-111.

[21] Thaipong, K., Boonprakob, U., Crosby, K., Cisneros-Zevallos, L., Byrne, D. H., Comparison of ABTS, DPPH, FRAP, and ORAC assays for estimating antioxidant activity from guava fruit extracts. J. Food Comp. Anal. 2006, 19, 669-675.

[22] Tanada-Palmu, P. S., Grosso, C. R., Effect of edible wheat gluten-based films and coatings on refrigerated strawberry (Fragaria ananassa) quality. Postharvest Biol. Technol. 2005, 36, 199-208.

[23] Radi, M., Akhavan-Darabi, S., Akhavan, H.-R., Amiri, S., The use of orange peel essential oil microemulsion and nanoemulsion in pectin-based coating to extend the shelf life of fresh-cut orange. J. Food Process. Preserv. 2017, 1-9.

[24] El-Anany, A., Hassan, G., Ali, F. R., Effects of edible coatings on the shelf-life and quality of Anna apple (Malus domestica Borkh) during cold storage. J. Food Technol. 2009, 7, 5-11.

[25] Khorram, F., Ramezanian, A., Hosseini, S. M. H., Shellac, gelatin and Persian gum as alternative coating for orange fruit. Sci. Hort. 2017, 225, 22-28. 
[26] Zeng, R., Zhang, A., Chen, J., Fu, Y., Impact of carboxymethyl cellulose coating enriched with extract of Impatiens balsamina stems on preservation of 'Newhall'navel orange. Sci. Hort. 2013, 160, 44-48.

[27] Cháfer, M., Sánchez-González, L., González- Martínez, C., Chiralt, A., Fungal decay and shelf life of oranges coated with chitosan and bergamot, thyme, and tea tree essential oils. J. Food Sci. 2012, 77.

[28] Ali, A., Maqbool, M., Ramachandran, S., Alderson, P. G., Gum arabic as a novel edible coating for enhancing shelf-life and improving postharvest quality of tomato (Solanum lycopersicum L.) fruit. Postharvest Biol. Technol. 2010, 58, 42-47.

[29] Mali, S., Grossmann, M. V. E., Effects of yam starch films on storability and quality of fresh strawberries (Fragaria ananassa). J. Agric. Food Chem. 2003, 51, 7005-7011.

[30] Benhabiles, M., Drouiche, N., Lounici, H., Pauss, A., Mameri, N., Effect of shrimp chitosan coatings as affected by chitosan extraction processes on postharvest quality of strawberry. J. Food Meas. Charact. 2013, 7, 215-221.

[31] Duan, J., Wu, R., Strik, B. C., Zhao, Y., Effect of edible coatings on the quality of fresh blueberries (Duke and Elliott) under commercial storage conditions. Postharvest Biol. Technol. 2011, 59, 71-79.

[32] Kim, I.-H., Oh, Y. A., Lee, H., Song, K. B., Min, S. C., Grape berry coatings of lemongrass oil-incorporating nanoemulsion. LWT-Food Sci. Technol. 2014, 58, 1-10.

[33] Benítez, S., Achaerandio, I., Sepulcre, F., Pujolà, M., Aloe vera based edible coatings improve the quality of minimally processed 'Hayward' kiwifruit. Postharvest Biol. Technol. 2013, 81, 29-36.

[34] Lamikanra, O., Fresh-cut fruits and vegetables: Science, technology, and market, CRC Press, Boca Raton, FL 2002. 
[35] Iglesias, I., Echeverría, G., Differential effect of cultivar and harvest date on nectarine colour, quality and consumer acceptance. Sci. Hort. 2009, 120, 41-50.

[36] Jitareerat, P., Paumchai, S., Kanlayanarat, S., Sangchote, S., Effect of chitosan on ripening, enzymatic activity, and disease development in mango (mangifera indica) fruit. $N$. Z. J. Crop Hortic. Sci. 2007, 35, 211-218.

[37] Lee, S. K., Kader, A. A., Preharvest and postharvest factors influencing vitamin C content of horticultural crops. Postharvest Biol. Technol. 2000, 20, 207-220.

[38] Shamloo, M., Sharifani, M., Garmakhany, A. D., Seifi, E., Alternation of secondary metabolites and quality attributes in Valencia Orange fruit (Citrus sinensis) as influenced by storage period and edible covers. J. Food Sci. Technol. 2015, 52, 1936-1947.

[39] Manzano, J., Diaz, A., Effect of storage time, temperature and wax coating on the quality of fruits of 'Valencia'orange (Citrus sinensis L.). Proc. Int. Soc. Trop Hort. 2001, 44, 24-29.

[40] Toğrul, H., Arslan, N., Carboxymethyl cellulose from sugar beet pulp cellulose as a hydrophilic polymer in coating of mandarin. J. Food Eng. 2004, 62, 271-279.

[41] Treviño-Garza, M. Z., García, S., del Socorro Flores- González, M., Arévalo- Niño, K., Edible active coatings based on pectin, pullulan, and chitosan increase quality and shelf life of strawberries (Fragaria ananassa). J. Food Sci. 2015, 80.

[42] Khaliq, G., Muda Mohamed, M. T., Ghazali, H. M., Ding, P., Ali, A., Influence of gum arabic coating enriched with calcium chloride on physiological, biochemical and quality responses of mango (Mangifera indica L.) fruit stored under low temperature stress. Postharvest Biol. Technol. 2016, 111, 362-369.

[43] Day, B., IV International Conference on Postharvest Science 553 2000, pp. 585-590.

[44] Kays, S. J., Post harvest physiology of perishable plant products, Vas Nostrand Rein Hold Book. AVI Publish. Co 1997. 
[45] Klimczak, I., Małecka, M., Szlachta, M., Gliszczyńska-Świgło, A., Effect of storage on the content of polyphenols, vitamin C and the antioxidant activity of orange juices. J. Food Comp. Anal. 2007, 20, 313-322.

[46] Ross, S. A., Ziska, D. S., Zhao, K., ElSohly, M. A., Variance of common flavonoids by brand of grapefruit juice. Fitoterapia 2000, 71, 154-161.

[47] Del Caro, A., Piga, A., Vacca, V., Agabbio, M., Changes of flavonoids, vitamin C and antioxidant capacity in minimally processed citrus segments and juices during storage. Food Chem. 2004, 84, 99-105.

[48] Rapisarda, P., Bianco, M. L., Pannuzzo, P., Timpanaro, N., Effect of cold storage on vitamin C, phenolics and antioxidant activity of five orange genotypes (Citrus sinensis (L.) Osbeck). Postharvest Biol. Technol. 2008, 49, 348-354.

[49] Lo Piero, A. R., Puglisi, I., Rapisarda, P., Petrone, G., Anthocyanins accumulation and related gene expression in red orange fruit induced by low temperature storage. J. Agric. Food Chem. 2005, 53, 9083-9088.

[50] Kalt, W., Forney, C. F., Martin, A., Prior, R. L., Antioxidant capacity, vitamin C, phenolics, and anthocyanins after fresh storage of small fruits. J. Agric. Food Chem. 1999, 47, 4638-4644.

[51] Meléndez-Martínez, A. J., Britton, G., Vicario, I. M., Heredia, F. J., The complex carotenoid pattern of orange juices from concentrate. Food Chem. 2008, 109, 546-553.

[52] Sánchez-Moreno, C., Plaza, L., de Ancos, B., Cano, M. P., Vitamin C, provitamin A carotenoids, and other carotenoids in high-pressurized orange juice during refrigerated storage. J. Agric. Food Chem. 2003, 51, 647-653.

[53] Bonilla, J., Atarés, L., Vargas, M., Chiralt, A., Effect of essential oils and homogenization conditions on properties of chitosan-based films. Food Hydrocoll. 2012, 26, 9-16. 
[54] Gil-Izquierdo, A., Gil, M. I., Ferreres, F., Effect of processing techniques at industrial scale on orange juice antioxidant and beneficial health compounds. J. Agric. Food Chem. 2002, 50, 5107-5114. 


\section{Figure captions}

Fig. 1. Total vitamin $\mathrm{C}$ (mg AAE/100 mL) of 'Valencia' orange juice stored at different storage conditions for four weeks. The values are the mean of four replicates. Different superscript letters at storage times show significant differences at $p<0.05$. Total vitamin $\mathrm{C}$ content in orange fruit before treatment was around $55.87 \pm 2.65$ (mg AAE/100 mL).

Fig. 2. Total phenolic content (mg GAE/100 mL) of 'Valencia' orange juice stored at different storage conditions for four weeks. The values are the mean of four replicates. Different superscript letters at storage times show significant differences at $p<0.05$. Total phenolic content in orange fruit before treatment was $86.79 \pm 5.05$ (mg GAE/100 mL).

Fig. 3. Total flavonoid content (mg RE/100 mL) of 'Valencia' orange juice stored at different storage conditions for four weeks. The values are the mean of four replicates. Different superscript letters at storage times show significant differences at $p<0.05$. Total flavonoid content in orange fruit before treatment was $27.31 \pm 2.31(\mathrm{mg} \mathrm{RE} / 100 \mathrm{~mL})$.

Fig. 4. Total anthocyanins content (mg CGE/100 mL) of 'Valencia' orange juice stored at different storage conditions for four weeks. The values are the mean of four replicates. Different superscript letters at storage times show significant differences at $p<0.05$. Total anthocyanins content in orange fruit before treatment was $11.56 \pm 1.04$ (mg CGE/100 mL).

Fig. 5. Total carotenoid content (mg $\beta$-carotene/L) of 'Valencia' orange juice stored at different storage conditions for four weeks. The values are the mean of four replicates. Different superscript letters at storage times show significant differences at $p<0.05$. Total carotenoid content in orange fruit before treatment was $11.73 \pm 0.97$ (mg $\beta$-carotene/L). 
Table 1. The titratable acidity (TA), pH and total soluble solids (TSS) of the 'Valencia' orange juice stored for one week and four weeks at different storage temperatures.*

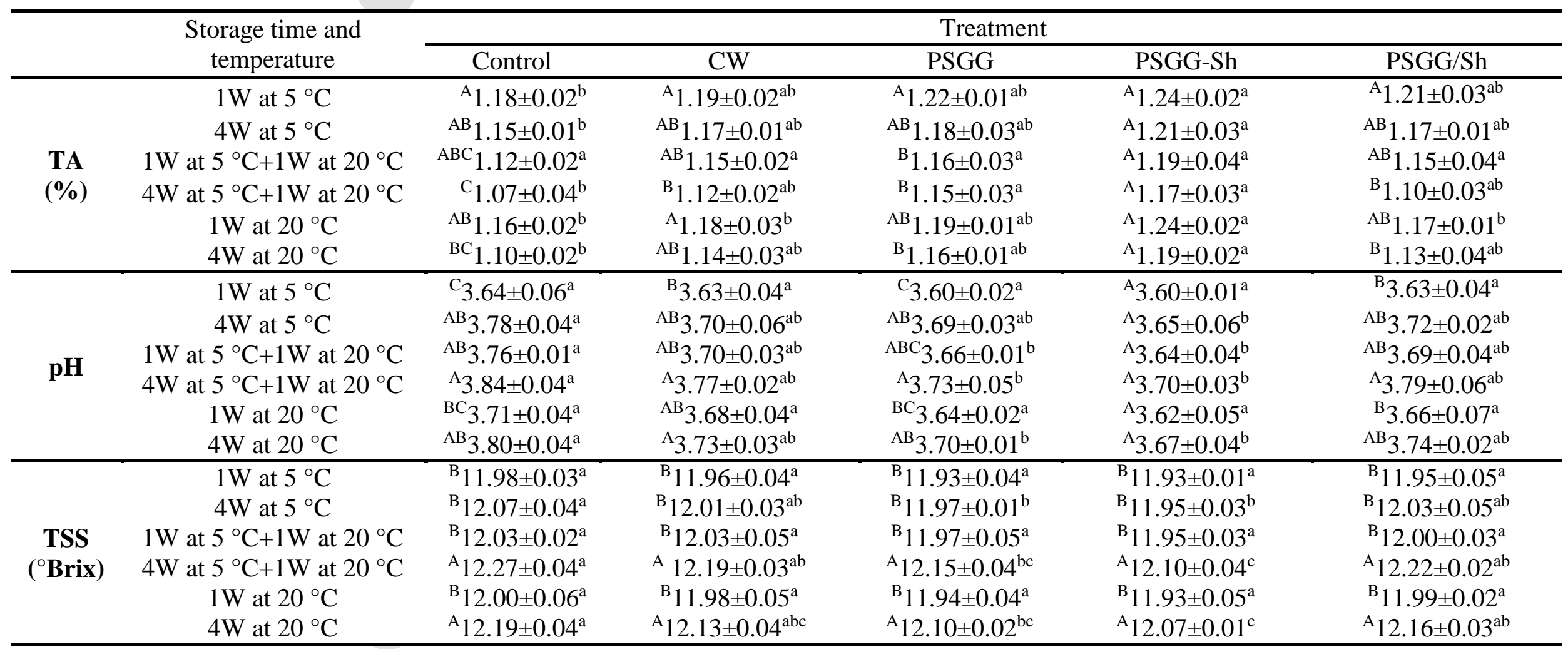

*The values are the mean of four replicates \pm standard deviation. Means at same row with different lower case are significantly different $(p<0.05)$; means at same column with different upper case are significantly different $(p<0.05)$. 
Table 2. Total antioxidant capacity DPPH and FRAP values of the 'Valencia' orange juice stored for one week and four weeks at different storage temperatures.*

\begin{tabular}{|c|c|c|c|c|c|c|}
\hline & \multirow{2}{*}{ Storage time and temperature } & \multicolumn{5}{|c|}{ Treatment } \\
\hline & & Control & $\mathrm{CW}$ & PSGG & PSGG-Sh & PSGG/Sh \\
\hline \multirow{6}{*}{$\begin{array}{c}\text { DPPH } \\
(\mathrm{mg} \mathrm{TE} / 100 \mathrm{~mL})\end{array}$} & $1 \mathrm{~W}$ at $5^{\circ} \mathrm{C}$ & $\mathrm{A}_{1} 121.50 \pm 2.89^{\mathrm{c}}$ & ${ }^{\mathrm{A}} 123.29 \pm 2.76^{\mathrm{bc}}$ & ${ }^{\mathrm{A}} 129.92 \pm 3.46^{\mathrm{ab}}$ & ${ }^{\mathrm{A}} 130.61 \pm 1.32^{\mathrm{a}}$ & ${ }^{\mathrm{A}} 127.91 \pm 1.26^{\mathrm{abc}}$ \\
\hline & $4 \mathrm{~W}$ at $5^{\circ} \mathrm{C}$ & ${ }^{\mathrm{BC}} 116.86 \pm 0.84^{\mathrm{d}}$ & ${ }^{\mathrm{AB}} 120.92 \pm 1.39^{\mathrm{C}}$ & ${ }^{\mathrm{ABC}} 125.60 \pm 2.60^{\mathrm{ab}}$ & ${ }^{\mathrm{AB}} 127.87 \pm 1.26^{\mathrm{a}}$ & ${ }^{\mathrm{CD}} 121.84 \pm 0.25^{\mathrm{bc}}$ \\
\hline & $1 \mathrm{~W}$ at $5^{\circ} \mathrm{C}+1 \mathrm{~W}$ at $20^{\circ} \mathrm{C}$ & ${ }^{A B} 118.22 \pm 1.49^{d}$ & ${ }^{\mathrm{AB}} 120.62 \pm 1.87^{\mathrm{cd}}$ & ${ }^{\mathrm{ABC}} 126.65 \pm 1.68^{\mathrm{ab}}$ & ${ }^{\mathrm{A}} 129.54 \pm 1.12^{\mathrm{a}}$ & ${ }^{\mathrm{BC}} 123.24 \pm 1.61^{\mathrm{bc}}$ \\
\hline & $4 \mathrm{~W}$ at $5^{\circ} \mathrm{C}+1 \mathrm{~W}$ at $20^{\circ} \mathrm{C}$ & ${ }^{\mathrm{D}} 111.86 \pm 0.84^{\mathrm{c}}$ & ${ }^{\mathrm{C}} 115.24 \pm 1.90^{\mathrm{b}}$ & ${ }^{\mathrm{C}} 121.48 \pm 1.47^{\mathrm{a}}$ & ${ }^{\mathrm{C}} 123.73 \pm 1.34^{\mathrm{a}}$ & ${ }^{\mathrm{E}} 116.72 \pm 0.49^{\mathrm{b}}$ \\
\hline & $1 \mathrm{~W}$ at $20^{\circ} \mathrm{C}$ & ${ }^{\mathrm{AB}} 119.96 \pm 0.70^{\mathrm{C}}$ & $\mathrm{AB}_{121.15} \pm 2.20^{\mathrm{C}}$ & ${ }^{\mathrm{AB}} 128.38 \pm 1.47^{\mathrm{ab}}$ & ${ }^{\mathrm{A}} 130.07 \pm 1.97^{\mathrm{a}}$ & ${ }^{\mathrm{AB}} 125.37 \pm 1.41^{\mathrm{b}}$ \\
\hline & $4 \mathrm{~W}$ at $20^{\circ} \mathrm{C}$ & ${ }^{\mathrm{CD}} 114.22 \pm 1.34^{\mathrm{C}}$ & ${ }^{\mathrm{BC}} 117.41 \pm 1.45^{\mathrm{bc}}$ & ${ }^{\mathrm{BC}} 123.65 \pm 1.97^{\mathrm{a}}$ & ${ }^{\mathrm{BC}} 125.34 \pm 1.24^{\mathrm{a}}$ & ${ }^{\mathrm{DE}} 119.34 \pm 1.04^{\mathrm{b}}$ \\
\hline \multirow{6}{*}{$\begin{array}{c}\text { FRAP } \\
(\mathrm{mg} \mathrm{TE} / 100 \mathrm{~mL})\end{array}$} & $1 \mathrm{~W}$ at $5^{\circ} \mathrm{C}$ & $\mathrm{A}^{\mathrm{A}} 105.00 \pm 1.35^{\mathrm{c}}$ & ${ }^{\mathrm{A}} 107.99 \pm 1.91 \mathrm{~b}^{\mathrm{c}}$ & ${ }^{\mathrm{A}} 123.10 \pm 0.49^{\mathrm{a}}$ & ${ }^{\mathrm{A}} 123.88 \pm 1.15^{\mathrm{a}}$ & ${ }^{\mathrm{A}} 110.84 \pm 1.38^{\mathrm{b}}$ \\
\hline & $4 \mathrm{~W}$ at $5^{\circ} \mathrm{C}$ & ${ }^{\mathrm{B}} 96.04 \pm 2.71^{\mathrm{c}}$ & ${ }^{\mathrm{B}} 102.50 \pm 0.85^{\mathrm{b}}$ & ${ }^{\mathrm{C}} 113.14 \pm 0.57^{\mathrm{a}}$ & ${ }^{\mathrm{B}} 116.10 \pm 1.15^{\mathrm{a}}$ & ${ }^{\mathrm{B}} 105.76 \pm 0.30^{\mathrm{b}}$ \\
\hline & $1 \mathrm{~W}$ at $5^{\circ} \mathrm{C}+1 \mathrm{~W}$ at $20^{\circ} \mathrm{C}$ & ${ }^{\mathrm{A}} 102.64 \pm 0.95^{\mathrm{C}}$ & ${ }^{\mathrm{AB}} 105.25 \pm 1.29^{\mathrm{bc}}$ & ${ }^{\mathrm{B}} 118.75 \pm 1.34^{\mathrm{a}}$ & ${ }^{\mathrm{A}} 121.53 \pm 1.13^{\mathrm{a}}$ & ${ }^{\mathrm{AB}} 108.48 \pm 2.11^{\mathrm{b}}$ \\
\hline & $4 \mathrm{~W}$ at $5^{\circ} \mathrm{C}+1 \mathrm{~W}$ at $20^{\circ} \mathrm{C}$ & ${ }^{\mathrm{B}} 93.51 \pm 0.86^{\mathrm{d}}$ & ${ }^{\mathrm{C}} 96.71 \pm 0.62^{\mathrm{c}}$ & ${ }^{\mathrm{D}} 105.21 \pm 1.50^{\mathrm{b}}$ & ${ }^{\mathrm{C}} 111.87 \pm 0.83^{\mathrm{a}}$ & D98.48 $\pm 1.44^{\mathrm{c}}$ \\
\hline & $1 \mathrm{~W}$ at $20^{\circ} \mathrm{C}$ & ${ }^{\mathrm{A}} 103.66 \pm 0.98^{\mathrm{d}}$ & ${ }^{\mathrm{A}} 106.35 \pm 0.98^{\mathrm{C}}$ & ${ }^{\mathrm{AB}} 120.47 \pm 1.09^{\mathrm{a}}$ & ${ }^{\mathrm{A}} 122.24 \pm 1.29^{\mathrm{a}}$ & ${ }^{\mathrm{A}} 110.24 \pm 0.37^{\mathrm{b}}$ \\
\hline & $4 \mathrm{~W}$ at $20^{\circ} \mathrm{C}$ & ${ }^{\mathrm{B}} 94.93 \pm 0.56^{\mathrm{e}}$ & ${ }^{\mathrm{C}} 98.15 \pm 0.73^{\mathrm{d}}$ & ${ }^{\mathrm{C}} 110.74 \pm 1.46^{\mathrm{b}}$ & ${ }^{\mathrm{BC}} 114.16 \pm 1.39^{\mathrm{a}}$ & ${ }^{\mathrm{C}} 101.50 \pm 0.39^{\mathrm{c}}$ \\
\hline
\end{tabular}

*The values are the mean of four replicates \pm standard deviation. Means at same row with different lower case are significantly different $(p<$

0.05); means at same column with different upper case are significantly different $(p<0.05)$. 

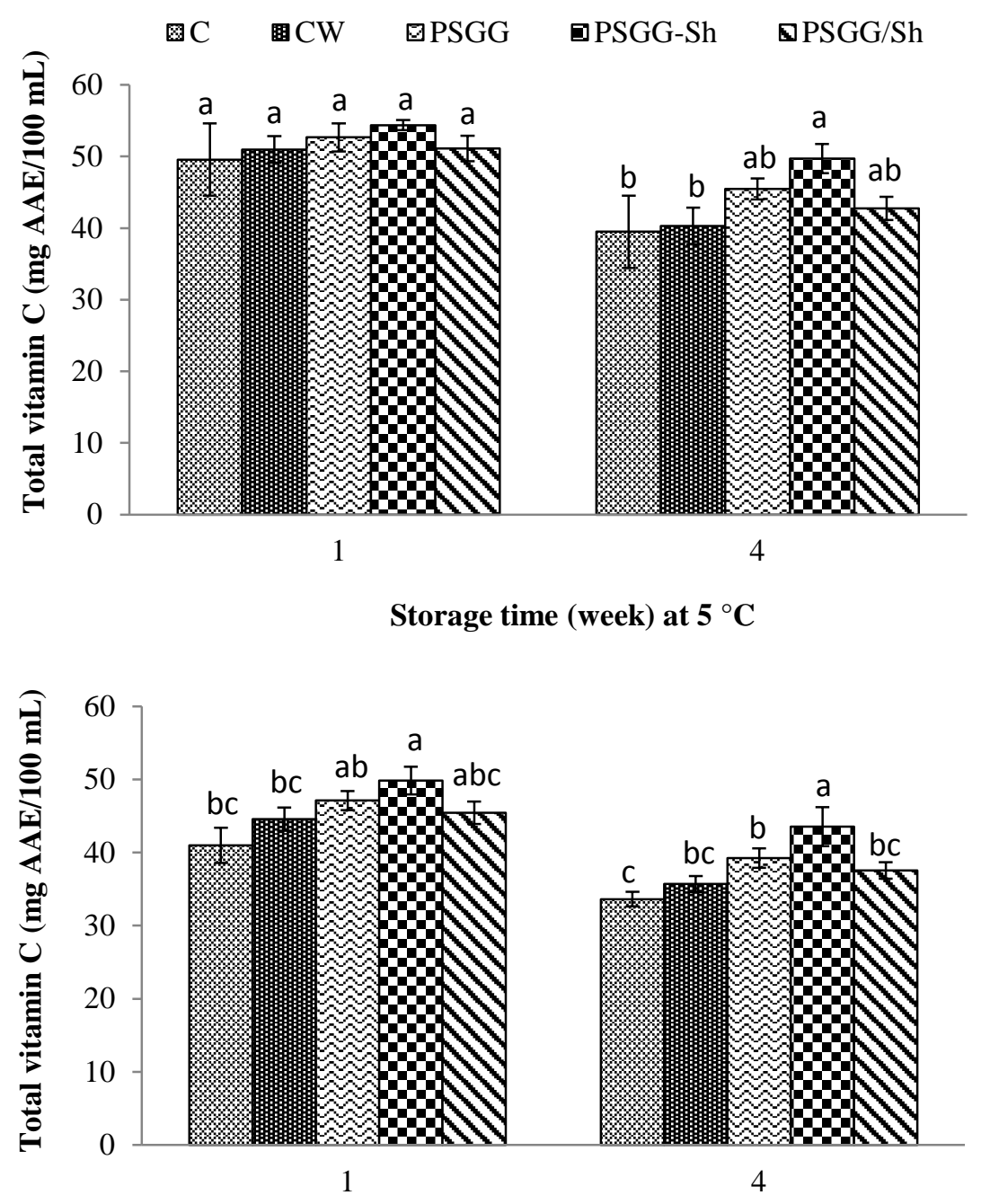

Storage time (week) at $5{ }^{\circ} \mathrm{C}+1$ week at $20{ }^{\circ} \mathrm{C}$

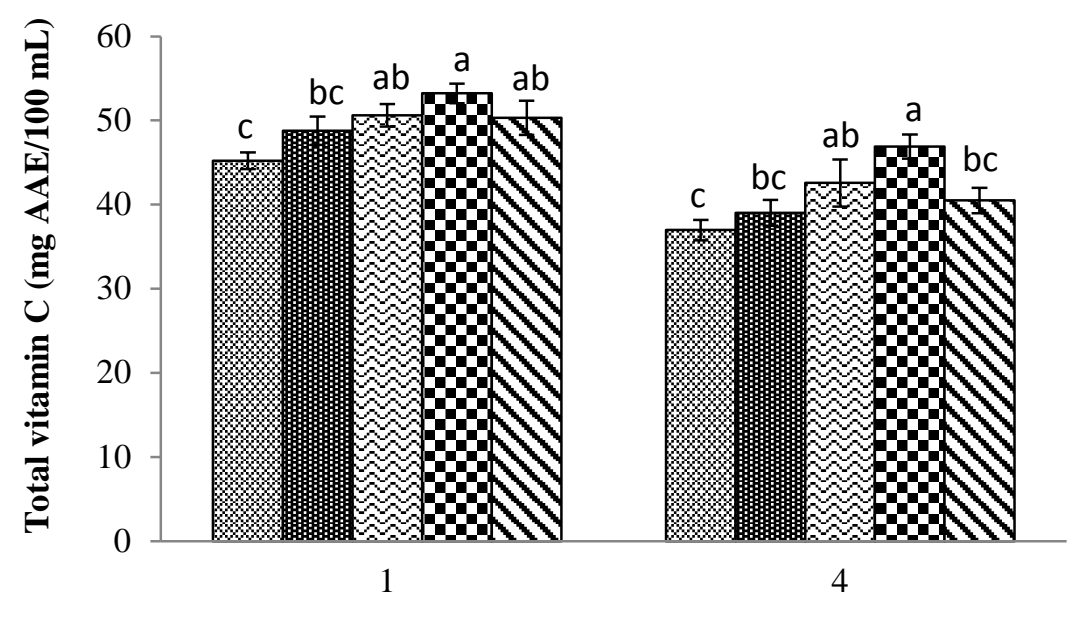

Storage time (week) at $20^{\circ} \mathrm{C}$

Fig. 1. 

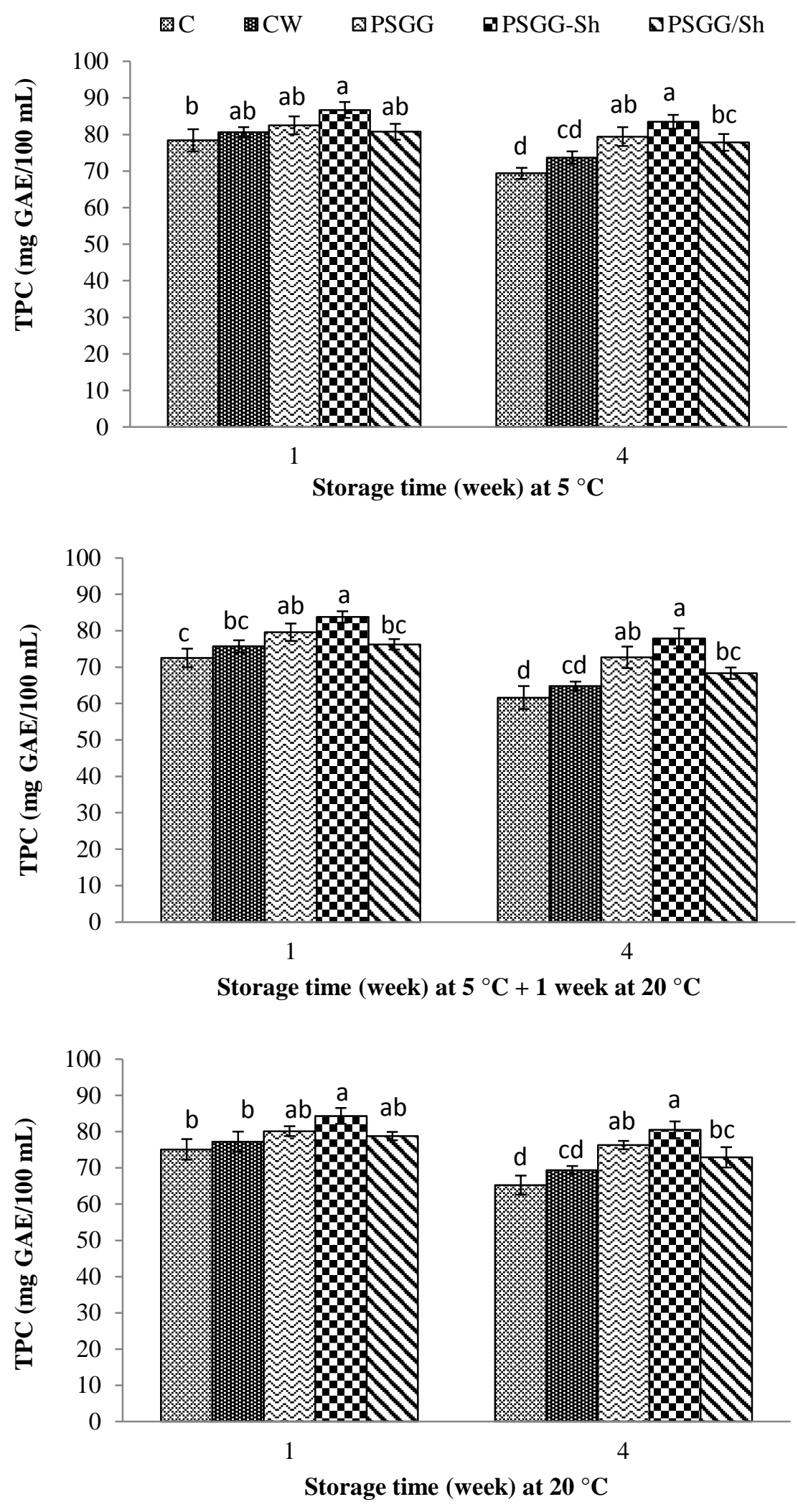

Fig. 2. 

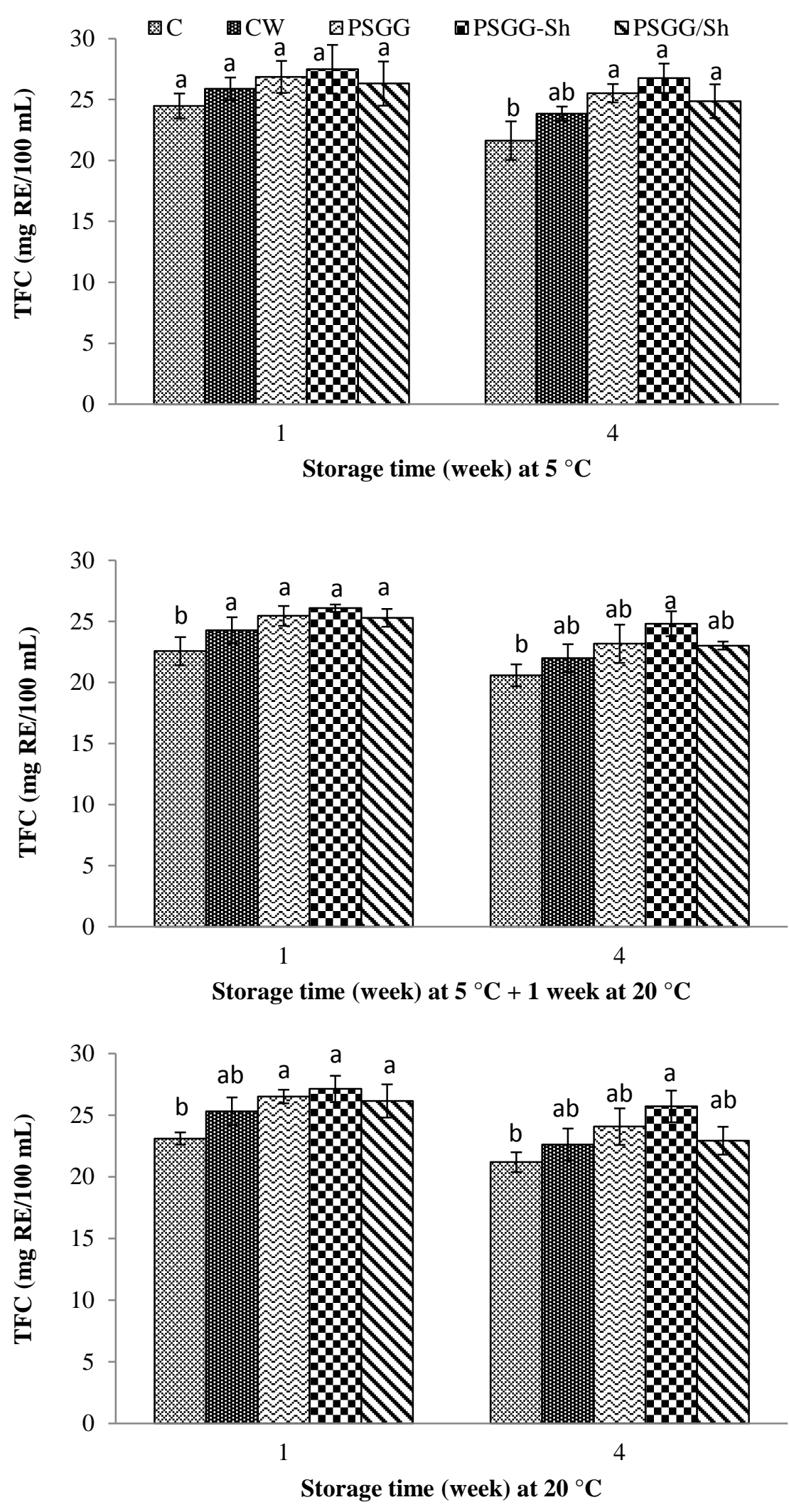

Fig. 3. 

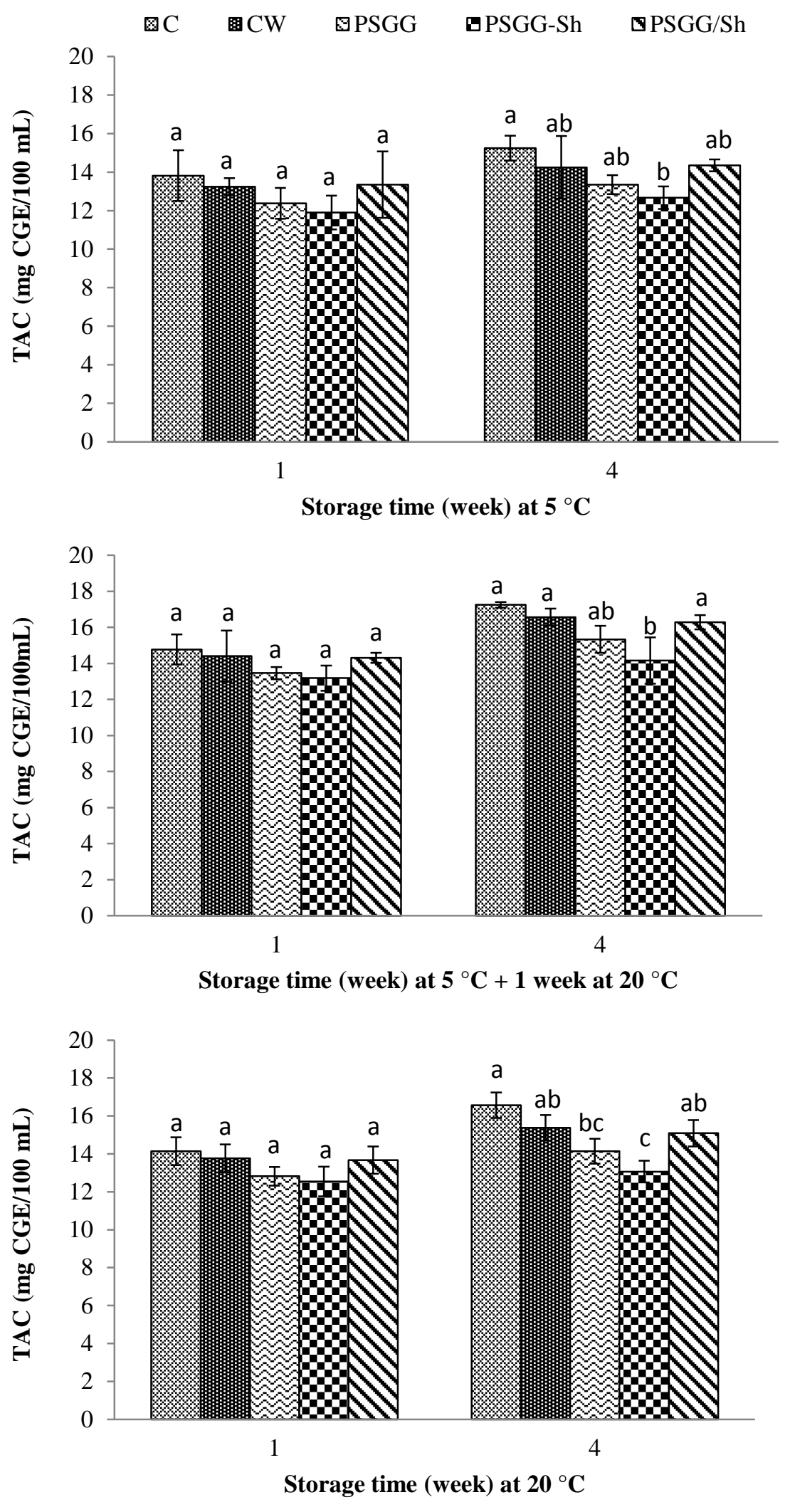

Fig. 4. 

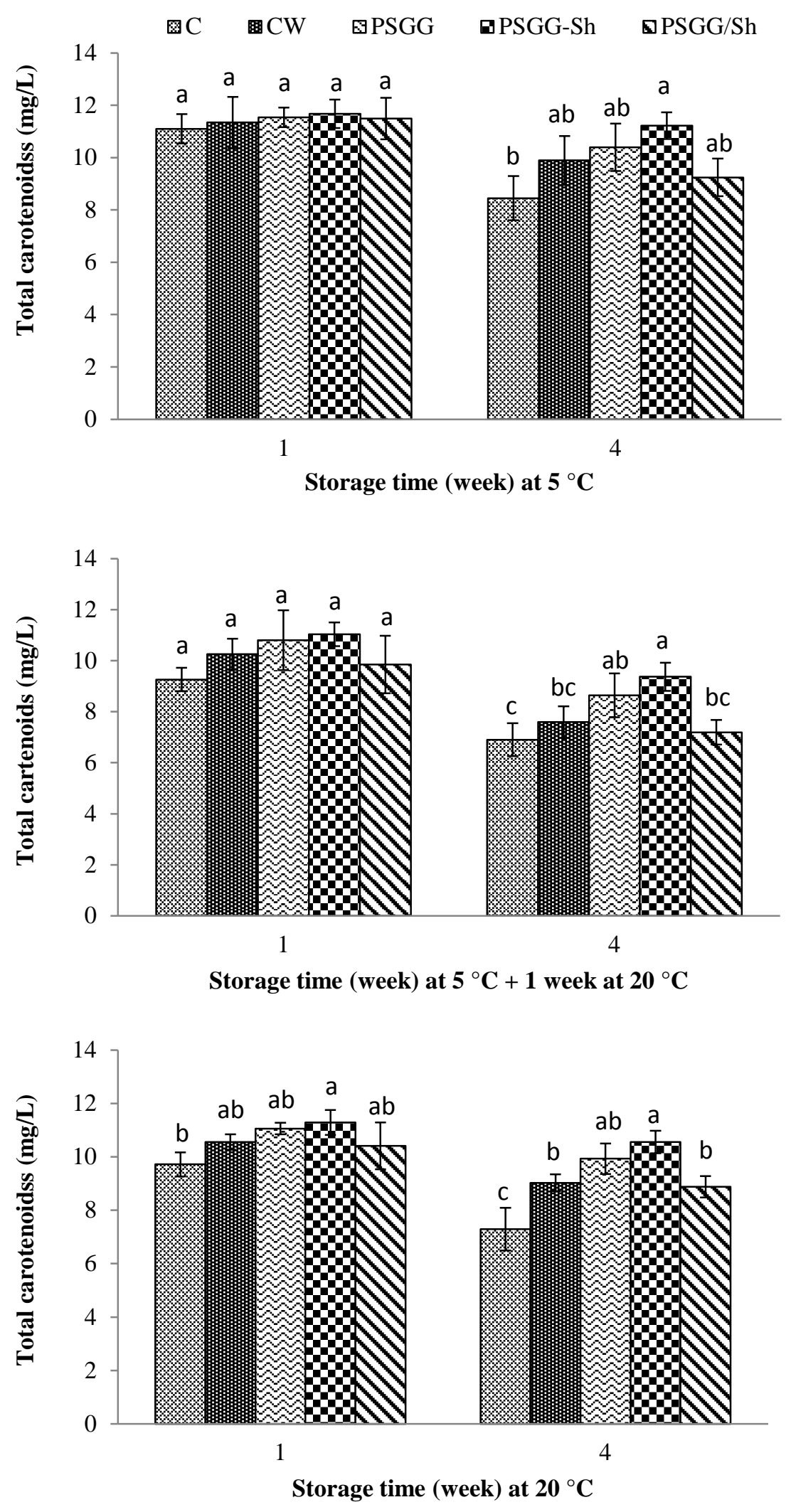

Fig. 5. 